ORIGINAL ARTICLE ARTIGO ORIGINAL

\title{
Hospitalization of schizophrenic patients in the public health system of Minas Gerais, Brazil
}

\author{
Hospitalização de pacientes esquizofrênicos no \\ Sistema Único de Saúde em Minas Gerais, Brasil
}

Laíse Sofia de Macedo Rodrigues', André Soares Santos', Augusto Afonso Guerra Júnior', Márcia Mascarenhas Alemão², Helian Nunes de Oliveira ${ }^{3}$, Edna Afonso Reis4, Carlos Eduardo Leal Vidal5,6, Cristina Mariano Ruas Brandão

DOI: 10.21115/JBES.v8.n3.p197-203

\section{Keywords:}

schizophrenia, economics, hospital, health economics, length of stay, costs and cost analysis

\begin{abstract}
Objectives: The aim of this study was to describe the socio-demographic and clinical variables, identify the determinants of length of stay and estimate the cost of inpatient treatment of schizophrenia in Minas Gerais, Brazil. Methods: A non-concurrent cohort was conducted in three psychiatric hospitals of Minas Gerais, Brazil. The data was collected from patients' records in loco. The association between dependent and independent variables was evaluated via linear regression. The costs were calculated through an absorption costing method. Results: 1,928 patients that met the inclusion criteria were identified. Most patients were male, had no life partner, studied no more than the middle school, had no occupation and lived in the city of hospital assistance. Haloperidol was the most prescribed antipsychotic drug. Risperidone was the most used second-generation antipsychotic, followed by olanzapine. Average length of stay was 30.3 days (SD = 37.5 days) and the median was 20 days. Female patients, living in cities other than the hospital's, with involuntary or mandatory hospitalizations and in use of a second-generation antipsychotic (SGA) and a first-generation antipsychotic (FGA) were associated to a longer length of stay. Average cost of hospitalization was R\$11,713.07 (US\$ 5,300.03) per hospitalization. Our results were corroborated by literature data. Conclusion: We found that most schizophrenic inpatients were male, single, had a low educational level and no occupational activity. The longer length of stay was associated to the socio-demographic and clinical variables, sex, place of residence, willingness to hospitalization of the patient and antipsychotic use.
\end{abstract}

Received on: 04/09/2016. Approved for publication on: 08/12/2016

1. Department of Social Pharmacy, College of Pharmacy, Universidade Federal de Minas Gerais (UFMG), Belo Horizonte, MG, Brazil. 2. Fundação Hospitalar do Estado de Minas Gerais (FHEMIG), Belo Horizonte, MG, Brazil.

3. Department of Public Health, College of Medicine, Universidade Federal de Minas Gerais (UFMG), Belo Horizonte, MG, Brazil. 4. Department of Statistics, Exact Sciences Institute, Universidade Federal de Minas Gerais (UFMG), Belo Horizonte, MG, Brazil. 5. Department of Psychiatry, Faculdade de Medicina de Barbacena (FAME), Barbacena, MG, Brazil.

6. Barbacena Psychiatric Hospital Centre, Fundação Hospitalar do Estado de Minas Gerais (FHEMIG), Barbacena, MG, Brazil. This study was funded by the Brazilian research promoting organizations Conselho Nacional de Desenvolvimento Cientifico e Tecnológico (CNPq) and Fundação de Amparo à Pesquisa do Estado de Minas Gerais (FAPEMIG). No pharmaceutical industries contributed with resources for this study. The authors declare to have no conflicts of interest that could influence the results of this study. This study was approved by the ethics committee of Fundação Hospitalar do Estado de Minas Gerais (FHEMIG) under CAAE protocol: 01934812.8.0000.5119.

Ethics statement: This study was approved by the ethics committee of Fundação Hospitalar do Estado de Minas Gerais (FHEMIG) under CAAE protocol: 01934812.8.0000.5119.

Conflicts of interest: The authors declare to have no conflicts of interest that could influence the results of this study. Corresponding author: Cristina Mariano Ruas Brandão. E-mail. crisruasbrandao@gmail.com

This study was presented in the Fórum Brasileiro de Assistência Farmacêutica e Farmacoeconomia, from July $26^{\text {th }}$ to $29^{\text {th }}, 2016$ in Salvador, Brazil. It is original and is not under consideration for publication in any other journal. All the authors have collaborated with the final text of the manuscript. 


\section{Palavras-chave:}

esquizofrenia, economia hospitalar, economia da saúde, tempo de internação, custos e análise de custos

\begin{abstract}
RESUMO
Objetivos: O objetivo deste estudo foi descrever as características sociodemográficas e clínicas, identificar os determinantes do tempo de permanência hospitalar e estimar o custo do tratamento hospitalar de pacientes com esquizofrenia em Minas Gerais, Brasil. Métodos: Uma coorte não concorrente foi conduzida em três instituições psiquiátricas de Minas Gerais, Brasil. Dados foram coletados dos prontuários dos pacientes in loco. A associação entre variáveis dependentes e independentes foi avaliada por meio de regressão linear. Os custos foram calculados por um método de Custeio de Absorção. Resultados: 1.928 pacientes foram incluídos no estudo. A maior parte deles era do sexo masculino, não tinha companheiro de vida, estudou até o ensino fundamental, não tinha ocupação e vivia na cidade em que receberam atenção hospitalar. Haloperidol foi o antipsicótico mais prescrito. Risperidona foi o antipsicótico atípico mais utilizado, seguido pela olanzapina. O tempo médio de hospitalização foi de 30,3 dias (DP = 37,5 dias) e a mediana, de 20 dias. Pacientes do sexo feminino, vivendo em cidades diferentes de onde receberam atenção hospitalar, em hospitalização involuntária ou mandatória e em uso de antipsicóticos típicos e atípicos, foram associados a tempos de internação mais longos. O custo médio de hospitalização foi de R\$11,713.07 (US\$ 5,300.03) por hospitalização. Os resultados concordam com dados da literatura. Conclusão: A maior parte dos pacientes com esquizofrenia internados nas instituições avaliadas era do sexo masculino, solteira, tinha baixo nível educacional e não tinha ocupação. O tempo de permanência mais longo foi associado às variáveis sociodemográficas e clínicas, sexo, local de residência, tipo de hospitalização quanto à voluntariedade e o uso de antipsicóticos.
\end{abstract}

\section{Introduction}

Schizophrenia is a debilitating chronic condition characterized by disorders in thought, affection and social behavior. It is costly to society due to its long course, high occurrence of comorbidities, necessity of hospitalizations and lack of a universally effective pharmacological treatment. Its prevalence is estimated to be between 0.3 and $1 \%$ worldwide (Mari \& Leitão, 2000; Daltio et al., 2007; Messias et al., 2007; Montgomery et al., 2013). The main objective of the psychiatric hospitalization is to intervene in crisis and to control severely ill patients, ensuring their safety and of others patients (Marcolino, 2007). The effects of the hospital care and length of inpatient stay are relevant indicators for public health policy.

Lieberman et al., (2005), in a pragmatic clinical trial of antipsychotics, observed that between $11 \%$ and $20 \%$ of the patients were hospitalized for exacerbation of schizophrenia during the 18 months of follow-up. Lay et al., (2007) observed, in a cohort study in Switzerland, that the number of admissions related to schizophrenia doubled between 1977 and 2004 and the length of stay was reduced by half (from 47 to 23 days). Schizophrenic patients experienced the largest drop of inpatient use in all diagnostic groups evaluated. The explanation for the drop in inpatient use is associated to the change from a hospitalocentric model to a community-based care and the introduction of new antipsychotic drugs in the market. For over a century, the Brazilian health system has adopted a hospitalocentric approach to mental health that marginalized patients from society (Brasil, 2011). Since the 70's, the hospitalocentric approach is being replaced by a community-based primary health care system that is reducing progressively the amount of hospital beds in combination with a expansion in primary health care networks and occupational inclusion programs for psychiatric patients. Between 2006 and 2010, there was a reduction of 6,832 psychiatric hospital beds in Brazil. A great part of those were funded by the public health system (Amarante, 2003; Brasil, 2005; 2011).

McEvoy (2007) described that, between 1991 and 2002, adopting the societal perspective, the costs related to inpatient care went down in the USA, after changes in policy and availability of drug treatments for schizophrenia. In fact, there was a reduction in psychiatric beds worldwide in the last few decades as a result of reforms in mental health care concepts and practices (Lay et al., 2007; Babalola et al., 2014). But, despite that, hospitalization costs are still the main direct cost driver of schizophrenia. Reducing length of stay and occurrence of relapses might be important to reduce schizophrenia treatment costs (Genduso \& Haley, 1997; Jones et al., 2006; Daltio et al., 2007). The aim of this study was to describe socio-demographic and clinical variables and estimate the cost of inpatient treatment of schizophrenia in the state of Minas Gerais, Brazil.

\section{Methods}

\section{Study design, place and data extraction}

An analysis of schizophrenic patients' hospitalizations between 2010 and 2013 was conducted, through a non-concurrent cohort, in three psychiatric facilities of Minas Gerais' public health system. The data was collected from patient's medical records in loco. The cost data was provided by hospi- 
tal Fundação Hospitalar do Estado de Minas Gerais' administration (FHEMIG) for the year of 2014 and examined through an absorption costing method.

\section{Sample}

The analysis included patients with at least 18 years of age, diagnosed with schizophrenia according to the F20 category of the International Statistical Classification of Diseases and Related Health Problems $10^{\text {th }}$ revision $(\mathrm{WHO}, 1997)$ at the moment of hospital discharge and that had a length of stay superior to 24 hours. Patients were excluded if the hospital records were unavailable or if the discharge diagnosis was different than schizophrenia.

\section{Analysis and data presentation}

The independent variables were divided in socio-demographic and clinical. The socio-demographic variables included name, date of birth, sex, place of residence, level of education, marital status and occupation. The variable place of residence was categorized into two groups: living in or out of the city of hospital care. The clinical variables included main diagnosis, willingness to hospitalization, drug use, comorbidities, number of admissions in the period, antipsychotic treatment and other medication used. The costs allocated to each center were related to: human resources, medication, other health materials, water, energy and administration.

Length of stay (in days), the dependent variable, was calculated subtracting the discharge date from the admission date for each hospitalization. The cost data is useful in the institution and is collected routinely for administrative purposes. The total cost is calculated by department with the apportionment of indirect costs. The unit of measure for the production is inpatient-days. The average cost of a hospitalization for schizophrenia was calculated considering the average cost per inpatient-day and the average length of stay of a schizophrenic patient. The data was extracted from the hospital administrative software SigCustos to a Microsoft Excel 2007 spreadsheet and the results were presented in tables. All costs are expressed in BRL (2014) and USD (1 USD = 2.21 BRL in 31/12/2014). Values were adjusted using the Broad Consumer Price Index (IPCA, in Portuguese) to June/2014.

Continuous variables were described in central tendency measures (mean and median) and dispersion measures (standard-deviation, SD). The categorical variables were described in absolute numbers and proportions. The relationship between dependent and independent variables were analyzed through a multiple linear regression model. The length of stay was transformed in a base 10 logarithm for the analysis. The data was processed in SPSS 21.0 and Minitab 17.

\section{Results}

During the period of the study, it was identified 1,928 patients that met the inclusion criteria. The total number of hospitalizations was 2,465, making an average of 1.28 hospitalizations per patient. Most patients were male (67.8\%), had no partner (83.8\%), studied no more than the middle school (65.1\%), had no occupation (67.7\%) and lived in the city of hospital care (54.9\%) (Table 1). Average age was 36.5 years-old ( $\mathrm{SD}=11.6$ years) and the median was 35 years-old.

Most patients (60.2\%) were diagnosed with paranoid schizophrenia and the average time from first diagnosis was 13.2 years ( $S D=10.2$ years). A large percentage of patients (46.5\%) reported drug use and $25.9 \%$ reported having at least one comorbidity (Table 2). Among the patients that reported comorbidities, $49.8 \%$ of them were associated to hypertension, diabetes, metabolic syndrome, heart disease, dyslipidemia, Chronic Obstructive Pulmonary Disease (COPD), panic disorder, Obsessive-Compulsive Disorder (OCD); the other $50.2 \%$ were composed by other mental disorders, neurological, infectious, autoimmune, endocrine, musculoskeletal and

Table 1. Socio-demographic profile of schizophrenic patients hospitalized in Brazilian psychiatric hospitals, between 2010 and 2013

\begin{tabular}{lc}
\hline Life partner & \\
\hline No partner & $1,615(83.8)$ \\
\hline Had a partner & $253(13.1)$ \\
\hline $\mathrm{NI}$ & $60(3.1)$ \\
\hline Education & $83(4.3)$ \\
\hline None & $949(49.2)$ \\
\hline Incomplete middle school & $223(11.6)$ \\
\hline Complete middle school & $102(5.2)$ \\
\hline Incomplete high school & $212(11.0)$ \\
\hline Complete high school & $26(1.3)$ \\
\hline Incomplete college degree & $10(0.5)$ \\
\hline College degree & $323(16.8)$ \\
\hline NI & \\
\hline Occupation & $1305(67.7)$ \\
\hline Unemployed or retired & $321(16.6)$ \\
\hline Employed & $302(15.7)$ \\
\hline NI & $1,058(54.9)$ \\
\hline Place of residence & $861(44.7)$ \\
\hline Hospital's city & $92.5)$ \\
\hline Other & \\
\hline NI & \\
\hline Total & \\
\hline
\end{tabular}

$\mathrm{NI}=$ Not Informed 
Table 2. Clinical profile of schizophrenic patients hospitalized in Brazilian psychiatric hospitals, between 2010 and 2013

\begin{tabular}{|c|c|}
\hline Diagnosis & \\
\hline F20.0 Paranoid schizophrenia & $1161(60.2)$ \\
\hline F20.1 Hebephrenic schizophrenia & $101(5.2)$ \\
\hline F20.2 Catatonic schizophrenia & $25(1.3)$ \\
\hline F20.3 Undifferentiated schizophrenia & $34(1.8)$ \\
\hline F20.4 Post-schizophrenic depression & $1(0.1)$ \\
\hline F20.5 Residual schizophrenia & $145(7.5)$ \\
\hline F20.6 Simple schizophrenia & $8(0.4)$ \\
\hline F20.8 Other schizophrenia & $16(0.8)$ \\
\hline F20.9 Schizophrenia unspecified & $437(22.7)$ \\
\hline \multicolumn{2}{|l|}{ Drug use } \\
\hline No & $653(33.9)$ \\
\hline Yes & $897(46.5)$ \\
\hline $\mathrm{NI}$ & $378(19.6)$ \\
\hline \multicolumn{2}{|l|}{ Comorbidities } \\
\hline No & $916(47.5)$ \\
\hline Yes & $500(25.9)$ \\
\hline $\mathrm{NI}$ & $512(26.6)$ \\
\hline \multicolumn{2}{|l|}{ Number of hospitalizations } \\
\hline One & $1,560(80.9)$ \\
\hline Two & $256(13.3)$ \\
\hline Three & $77(4.0)$ \\
\hline Four & $24(1.2)$ \\
\hline Five or more & $11(0.6)$ \\
\hline Total & 1.928 \\
\hline
\end{tabular}

$\mathrm{NI}=$ Not Informed .

respiratory diseases. Most patients (80.9\%) were hospitalized only once during the period of study.

Most hospitalizations were involuntary (66.5\%). In 96.4\% of the hospitalizations, at least one antipsychotic drug was prescribed. In most of them, the prescription was of one FGA (38.0\%) or two or more FGAs (36.1\%). SGAs were employed in $22.3 \%$ of the hospitalizations. Risperidone was the most used SGA, in $9.1 \%$ of the discharge prescriptions, followed by olanzapine, in 6.5\% (Table 3). The most used concomitant medications were benzodiazepines $(65.1 \%$ of the hospitalizations), anticholinergic drugs (62.0\%), antiepileptic drugs (26.6\%), antidepressants (6.1\%), mood stabilizers (2.7\%) and barbiturates (1.4\%).

The final multiple linear regression model explains only $11 \%$ of the total variation in the length of stay. Female patients, living in cities other than the hospital's, with involuntary or mandatory hospitalizations and in use of a SGA and a FGA were associated to a longer length of stay (Table 4).
Table 3. Characteristics of the hospitalizations of schizophrenic patients in Brazilian psychiatric hospitals, between 2010 and 2013

\begin{tabular}{lc}
\hline Willingness of the patient & 64,242 \\
\hline Voluntary & $1.638(66.5)$ \\
\hline Involuntary & $39(1.6)$ \\
\hline Mandatory & $86(3.5)$ \\
\hline $\mathrm{NI}$ & \\
\hline Drug prescription in hospital discharge & $936(38.0)$ \\
\hline Only one FGA & $287(11.6)$ \\
\hline Only one SGA & $891(36.1)$ \\
\hline Two or more FGAs & $8(0.3)$ \\
\hline Two or more SGAs & $256(10.4)$ \\
\hline FGA and SGA & $87(3.6)$ \\
\hline No antipsychotic drug & $225(9.1)$ \\
\hline SGA prescribed in hospital discharge & $38(1.5)$ \\
\hline Risperidone & $24(1.0)$ \\
\hline Quetiapine & $160(6.5)$ \\
\hline Ziprasidone & $96(3.9)$ \\
\hline Olanzapine & $8(0.3)$ \\
\hline Clozapine & $1914(77.6)$ \\
\hline Two or more SGAs & 2,465 \\
\hline No SGA & \\
\hline Total & \\
\hline &
\end{tabular}

$\mathrm{NI}=$ Not Informed; FGA = First-generation antipsychotic; SGA = Second generation antipsychotic.

Table 4. Final multiple linear regression model: factors associated to longer length of stay (in log10) in Brazilian psychiatric hospitals, 2010 to 2013

\begin{tabular}{lcc}
\hline Variable & Coefficient $\beta$ & P-value \\
\hline Sex & 1.16 & \\
\hline Female & & 0.002 \\
\hline Place of residence & -1.65 & 0.000 \\
\hline Same as the hospital & & \\
\hline Willingness & 1.31 & 0.000 \\
\hline Involuntary & 3.32 & 0.000 \\
\hline Mandatory & & \\
\hline Drugs & 1.54 & 0.000 \\
\hline FGA + SGA & & \\
\hline
\end{tabular}

The average cost per inpatient-day was equal to $R \$ 386.57$ (US\$174.92) (Table 5). Average length of stay was 30.3 days $(S D=37.5)$ and the median was 20 days. Average cost of hospitalization of schizophrenic patients was $\mathrm{R} \$ 11,713.07$ (US\$ 5,300.03). 
Table 5. Total annual costs and production of inpatient care sectors of Brazilian psychiatric hospitals (2014)

\begin{tabular}{lccc}
\hline Hospital & Total Cost (R\$) & $\begin{array}{c}\text { Production } \\
\text { (inpatient- } \\
\text { days) }\end{array}$ & $\begin{array}{c}\text { Average (R\$/ } \\
\text { inpatient-day) }\end{array}$ \\
\hline IRS & $13,851,136.96$ & 34509 & 401.38 \\
\hline HGV & $11,316,663.44$ & 27493 & 411.62 \\
\hline CHPB & $3,446,819.22$ & 12020 & 286.76 \\
\hline Total & $28,614,619.62$ & 74022 & 386.57 \\
\hline
\end{tabular}

\section{Discussion}

The sociodemographic data has shown that most schizophrenic inpatients were male, single, had a low educational level and did not work. Like this study, other papers reported a higher number of male subjects in psychiatric hospital beds (Herrera, 1997; Gomes et al., 2002; Kelly et al., 2004; Souza et al., 2008; Daltio et al., 2011; Gorwood, 2011), characteristic that might be associated with the most severe course of the disease in men, considering that the prevalence of schizophrenia is not very different between sexes (Mari \& Leitão, 2000). Durbin et al., (2014) found schizophrenic men to be in a higher risk for hospitalization ( $\mathrm{OR}=1.42)$. Long-term outcomes of schizophrenia might be more severe in men, regarding mortality, suicide and homelessness (Ran et al., 2015). Other studies also found that most patients were single or had no life partner (Gomes et al., 2002; Daltio et al., 2011), were retired or unemployed (Daltio et al., 2011) and had low educational level (Gomes et al., 2002; Daltio et al., 2011).

Paranoid schizophrenia was considered the most common diagnosis $(60.2 \%)$, followed by residual schizophrenia (7.5\%) and hebephrenic schizophrenia (5.2\%). Other studies conducted in Brazil found paranoid schizophrenia in 40 to 43.7\% of the patients (Messias et al., 2000; Ferreira et al., 2007). Some of the comorbidies reported were already associated with schizophrenia. Cahoon et al., (2013) observed higher odds of hospitalization for schizophrenic patients in bacterial pneumonia, urinary tract infection, dehydration, perforated appendix, congestive heart failure, COPD, asthma, diabetes mellitus long-term complications, diabetes mellitus short-term complications and uncontrolled diabetes. Our study found that $25.9 \%$ of the patients reported at least one comorbidity. The low comorbidities rate observed might be related to the incomplete filling of medical records. Carney et al., (2006) reported that $71.4 \%$ of the patients had comorbidities and were more commonly admitted in general health services. Schoepf et al., (2012) observed that hospitalized schizophrenic patients had worse clinical condition due to high prevalence of comorbidities.

The mean length of stay for schizophrenic patients in this study was found to be approximately 30 days. Other authors found similar results, ranging from 21 to 50 days (Hibberd \& Trimboli, 1982; Lieberman et al., 1993; Brenner et al., 1999; Souza et al., 2008; Daltio et al., 2011; Yang et al., 2011). The mean length of stay found in this work complies with the recommendation of the Brazilian Ministry of Health maximum length of stay of 30 days (Brasil, 1990). Even with the movement for the deinstitutionalization of psychiatric patients, it is possible to observe many long-stay hospitalized patients, since the new primary health care model is yet being consolidated.

Souza et al., (2008) evaluated the length of hospital stay categorized by diagnostic categories in Mato Grosso do Sul, Brazil. Unlike our findings, the length of hospital stay was not found to be influenced by sex or age. However, patients that lived more than $200 \mathrm{~km}$ from the hospital city were associated to a larger length of stay ( $p$-value $<0.05$ ), as observed. The mean length of stay observed for schizophrenic patients was also close to 30 days (29.64 days [SD $=12.85]$ ).

Hospitalization costs are the most relevant direct cost of the treatment of schizophrenia. Reducing the length of stay or the relapse rate may be a key aspect to reduce the costs of schizophrenia (Genduso \& Haley, 1997; Knapp et al., 2004; Jones et al., 2006; Daltio et al., 2007). Leitão et al., (2006) measured the direct costs of schizophrenia for the public health system. They found that most expenses were related to inpatient care (about 80\%). The medication accounted for only a small portion of the total costs (7.2\%). Other authors had already shown that medication is not among the most relevant costs of schizophrenia (Genduso \& Haley, 1997; Jones et al., 2006). Costs of prescription are not among the most relevant costs of schizophrenia, but many of the relapses related to schizophrenia may be associated to low medication adherence and concordance. The application of antipsychotics in Long-Acting Injections formulations may be a way to reduce the costs of inpatient care (Tay-Teo et al., 2014). In accordance with our work, Daltio et al., (2011) found that the most commonly used antipsychotic drugs during hospitalization were the FGAs haloperidol, haloperidol decanoate and chlorpromazine and the most commonly used SGA was risperidone, followed by olanzapine. The use of newer antipsychotic drugs seems to be one of the factors associated with the drop in length of stay observed in the last decades. Their improved efficacy and tolerability makes compliance more likely and, therefore, reduce rates of relapse (Jukic et al., 2013).

This work estimated that the cost of inpatient treatment of schizophrenia was about BRL 11,713.07 (USD 5,300.03) per hospitalization. Daltio et al., (2011), in an evaluation of direct health care costs of schizophrenia in 2006, found that the mean annual direct medical costs of schizophrenia relapses per patient ranged from 2,397.00 BRL to 8,167.00 BRL (BRL(2014) 3,921.50 [USD 1,774.43] to BRL(2014) 13,361.25 [USD $6,045.81])$. The authors found that the public hospital evaluated had the largest mean annual cost of relapse, even when 
compared to a private hospital. Tay-Teo et al., (2014) indicated that schizophrenia relapses in Brazil were responsible for a cost of 1,07 billion BRL in 2013. The economic cost of a relapse per patient was estimated in BRL 12,108.00 (BRL(2014) 12,961.04 [USD 5,864.72]) considering direct and indirect costs. The direct costs accounted for $67.3 \%$ of the total cost. As our work studied three public hospitals administered by the public health system, the estimate of Daltio et al., (2011) falls very close to our findings.

A high occurrence of drug abuse was detected in the patients evaluated (57.9\%). Alcohol was the most frequent (54.5\%), followed by tobacco (51.6\%), crack (27.5\%) and cannabis (22.3\%). Carney et al., (2006) observed that 27.2\% of the patients evaluated were drug users (nicotine, alcohol and illegal drugs). The characteristics of the disease may predispose patients for the use of certain illicit drugs (Green \& Brown, 2006). Patients that develop the disease younger and show better pre-morbid conditions are more likely to abuse alcohol (Mueser et al., 1992). The alcohol abuse might be related to a relief of anxiety symptoms (Batki et al., 2009). The abuse of drugs can make patient's prognosis worse, being associated to declines in social living, higher hospitalization rates, non-adherence and therapeutic failure. The symptoms of the abstinence syndrome mimic the symptoms of schizophrenia, making it difficult to diagnose. Evidences suggest that the use of cannabis may be a precipitant factor to psychotic crisis or a self-medication phenomenon (Neto et al., 2007). Smoking can influence the pharmacological treatment through the induction of microsomal enzymes (Brunton et al., 2011).

Schizophrenia was found to be the most frequent cause of psychiatric hospitalization by some authors (Dhadphale \& Shaikh, 1981; Gomes et al., 2002; Souza et al., 2008). Beyond the rate of re-hospitalization, length of stay and the effects of inpatient care are important for mental health policies (Babalola et al., 2014). In a Cochrane Collaboration systematic review, Babalola et al., (2014) showed that shorter length of stay is associated to better social functioning and employment of severe mental ill patients. Gorwood (2011) showed that outpatients were more likely to be employed, better educated, living with family and to have a caregiver. No difference in death rates or readmission rates were found between patients treated with long or short stay hospitalization. It is important to add that the advantage seen in short-term hospitalization does not mean that no patients should need longer lengths of stay. Although, considering that the aim of the treatment of schizophrenia is not only to reduce the symptoms, but also to improve social functioning and employability, reducing number of relapses and length of stay might be good to achieve successful treatment outcomes.

The access of schizophrenic patients to primary health care might be worse than the rest of the population. Ambulatory care-sensitive hospitalizations, defined as hospitaliza- tions preventable by timely and effective outpatient care, are also more common in schizophrenic patients (Cahoon et al., 2013). That way, the improvement of the treatment of schizophrenia associated with the access to quality primary health care can also reduce the cost of hospitalizations for other causes. The reduction of the relapses and length of stay in schizophrenic patients is associated to a reduction in economic costs, which are important to the financial health of the public system, and also to the improvement of the patients functioning and quality of life. The knowledge of the factors associated to relapses and longer lengths of stay can be used by policy maker to improve the prognosis of patients with schizophrenia.

The cost analysis was not performed by schizophrenic patient, but with the average cost of a psychiatric bed in the three psychiatric hospitals evaluated. There could be variation between diagnoses that influence the costs of treatment. The length of stay was measured for each patient, no considerable error is expected. Some difficulties were seen in the extraction of data from patient records. Part of it is due to illegibility or absence of information.

In conclusion, we found that most schizophrenic inpatients were male, single, had a low educational level and no occupational activity. The cost of hospitalization was considered high and the long length of stay was associated to the socio-demographic and clinical variables, sex, place of residence, willingness of the patient and antipsychotic use.

\section{Acknowledgements}

this study was conducted with operational support of Fundação Hospitalar do Estado de Minas Gerais (FHEMIG) and Grupo de Pesquisa de Farmacoepidemiologia of UFMG. It was financially supported by Centro Colaborador do SUS (CCATES), Conselho Nacional de Desenvolvimento Científico e Tecnológico (CNPq) and Fundação de Amparo à Pesquisa do Estado de Minas Gerais (FAPEMIG).

\section{References}

Amarante P. Saúde mental, políticas e instituições: programa de educação à distância. Rio de Janeiro: EAD/ENPS, 2003.

Babalola O, Gormez V, Alwan NA, Johnstone P, Sampson S. Length of hospitalisation for people with severe mental illness. Cochrane Database Syst Rev. 2014;(1):CD000384.

Batki SL, Meszaros ZS, Strutynski K, Dimmock JA, Leontieva L, Ploutz-Snyder $\mathrm{R}$, et al. Medical comorbidity in patients with schizophrenia and alcohol dependence. Schizophr Res. 2009;107(2-3):139-46.

Brasil. Orientações para funcionamento e supervisão dos serviços de saúde mental. Brasília: Ministério da Saúde, 1990.

Brasil. Reforma psiquiátrica e política de saúde mental no Brasil. In: (Ed.). Conferência Regional de Reforma dos Serviços de Saúde Mental: 15 anos depois de Caracas. Brasília: OPAS, 2005. 
Brasil. Saúde mental no SUS: as novas fronteiras da Reforma Psiquiátrica: Relatório de Gestão 2007/2010. Braślia: Ministério da Saúde, 2011.

Brenner MK, Cardoso VM, Oliveira RLV, Fensterseifer GP, Barraz ACG, Boeira LB, et al. Mudanças na clientela de internados em hospital psiquiátrico. J Bras Psiquiatr. 1999;48(9):415-20.

Brunton LL, Chabner BA, Knollmann BC. Goodman \& Gilman's The Pharmacological Basis of Therapeutics. 12. McGraw-Hill Education, 2011.

Cahoon EK, McGinty EE, Ford DE, Daumit GL. Schizophrenia and potentially preventable hospitalizations in the United States: a retrospective crosssectional study. BMC Psychiatry. 2013;13:37.

Carney $C P$, Jones $L$, Woolson RF. Medical comorbidity in women and men with schizophrenia: a population-based controlled study J Gen Intern Med. 2006;21(11):1133-7.

Daltio CS, Mari JDJ, Ferraz MB. Overview about pharmacoeconomics analysis and burden-of-illness in schizophrenia. Rev Psiquiatr Clín (Säo Paulo). 2007;34(supl. 2):208-12.

Daltio CS, Mari JJ, Ferraz MB. Direct medical costs associated with schizophrenia relapses in health care services in the city of Sao Paulo. Rev Saude Publica. 2011;45(1):14-23.

Dhadphale M, Shaikh SP. Psychiatric diagnosis of 236 admissions seen at Ndola, Zambia. East Afr Med J. 1981;58(1):65-71.

Durbin A, Rudoler D, Durbin J, Laporte A, Callaghan RC. Examining patient race and area predictors of inpatient admission for schizophrenia among hospital users in California. J Immigr Minor Health. 2014;16(6):1025-34.

Ferreira AAA, Sena GS, Galvão MVM, Felix RHM, Mendonça RM, Guerra GCB, et al. Tendência temporal da esquizofrenia: um estudo realizado no âmbito hospitalar. J Bras Psiquiatr. 2007;56(3):157-61.

Genduso LA, Haley JC. Cost of illness studies for schizophrenia: components, benefits, results, and implications. Am J Manag Care. 1997;3(6):873-7.

Gomes MPC, Couto MCV, Pepe VLE, Almeida LM, Delgado PGG, Coutinho ESF. Censo dos pacientes internados em uma instituição asilar no Estado do Rio de Janeiro: dados preliminares. Cad Saúde Pública. 2002;18(6):1803-7.

Gorwood P. Factors associated with hospitalisation of patients with schizophrenia in four European countries. Eur Psychiatry. 2011;26(4):224-30.

Green Al, Brown ES. Comorbid schizophrenia and substance abuse. J Clin Psychiatry. 2006;67(9):e08.

Herrera F. Incidência de esquizofrenia en el hospital psiquiátrico Julio Endara, 1995. Rev. Fac. Cienc. Méd (Quito). 1997;22(1):36-9.

Hibberd T, Trimboli F. Correlates of successful short-term psychiatric hospitalization. Hosp Community Psychiatry. 1982;33(10):829-33.

Jones PB, Barnes TR, Davies L, Dunn G, Lloyd H, Hayhurst KP, et al. Randomized controlled trial of the effect on Quality of Life of second- vs first-generation antipsychotic drugs in schizophrenia: Cost Utility of the Latest Antipsychotic Drugs in Schizophrenia Study (CUtLASS 1). Arch Gen Psychiatry. 2006;63(10):1079-87.

Jukić V, Savić A, Herceg M. Importance of the newer generations of antipsychotics in reducing schizophrenia hospitalization rates. Psychiatr Danub. 2013;25(3):329-33.

Kelly BD, Clarke M, Browne S, McTigue O, Kamali M, Gervin M, et al. Clinical predictors of admission status in first episode schizophrenia. Eur Psychiatry. 2004;19(2):67-71.
Knapp M, Mangalore R, Simon J. The global costs of schizophrenia. Schizophr Bull. 2004;30(2):279-93.

Lay B, Nordt C, Rössler W. Trends in psychiatric hospitalisation of people with schizophrenia: a register-based investigation over the last three decades. Schizophr Res. 2007;97(1-3):68-78.

Leitão RJ, Ferraz MB, Chaves AC, Mari JJ. Cost schizophrenia: direct costs and use of resources in the State of São Paulo. Rev Saúde Pública. 2006;40(2):304-9.

Lieberman JA, Stroup TS, McEvoy JP, Swartz MS, Rosenheck RA, Perkins DO, et al. Effectiveness of antipsychotic drugs in patients with chronic schizophrenia. N Engl J Med. 2005;353(12):1209-23.

Lieberman PB, McPhetres EB, Elliott B, Egerter E, Wiitala S. Dimensions and predictors of change during brief psychiatric hospitalization. Gen Hosp Psychiatry. 1993;15(5):316-24.

Marcolino J. Psiquiatria e psicoterapia no âmbito institucional. In: Alves L. (Ed.). Ética e psiquiatria. São Paulo: Conselho Regional de Medicina do Estado de São Paulo, 2007.

Mari JJ, Leitão RJ. A epidemiologia da esquizofrenia. Rev Bras Psiquiatr. 2000;22(supl. 1):15-7.

Mcevoy JP. The costs of schizophrenia. J Clin Psychiatry. 2007;68 Suppl 14:4-7.

Messias E, Sampaio JJ, Messias NC, Kirkpatrick B. Epidemiology of schizophrenia in northeast Brazil. J Nerv Ment Dis. 2000;188(2):118-20.

Messias EL, Chen CY, Eaton WW. Epidemiology of schizophrenia: review of findings and myths. Psychiatr Clin North Am. 2007;30(3):323-38.

Montgomery W, Liu L, Stensland MD, Xue HB, Treuer T, Ascher-Svanum H. The personal, societal, and economic burden of schizophrenia in the People's Republic of China: implications for antipsychotic therapy. Clinicoecon Outcomes Res. 2013;5:407-18.

Mueser KT, Yarnold PR, Bellack AS. S. Diagnostic and demographic correlates of substance abuse in schizophrenia and major affective disorder. Acta Psychiatr Scand. 1992;85(1):48-55.

Araripe Neto AGA, Bressan RA, Busatto Filho G. Fisiopatologia da esquizofrenia: aspectos atuais. Rev Psiq Clín. 2007;34(supl. 2);198-203.

Ran MS, Mao WJ, Chan CL, Chen EY, Conwell Y. Gender differences in outcomes in people with schizophrenia in rural China: 14-year follow-up study. Br J Psychiatry. 2015;206(4):283-8.

Schoepf D, Uppal H, Potluri R, Heun R. Physical comorbidity and its relevance on mortality in schizophrenia: a naturalistic 12-year follow-up in general hospital admissions. Eur Arch Psychiatry Clin Neurosci. 2012;27(1):33-42.

Souza JC, Souza N, Magna LA. Tempo médio de hospitalização e categorias diagnósticas em hospital psiquiátrico. J Bras Psiquiatr. 2008;7(2):112-6.

Tay-Teo K, Pezzullo L, Violin BB, Dias T, Pititto L, Guarniero F. O custo da recaída no tratamento da esquizofrenia no Brasil. J Bras Econ Saúde. 2014;6(2):102-5.

World Health Organization (WHO). CID-10 Classificação Estatística Internacional de Doenças e Problemas Relacionados à Saúde. São Paulo: Universidade de São Paulo, 1997.

Yang SL, Qian MC, Lu W, et al. Cost of treating medical conditions in psychiatric inpatients in Zhejiang, China. Shanghai Arch Psychiatry. 2011;23(6):329-37.

Yang S, et al. Cost of treating medical conditions in psychiatric inpatients in Zhejiang, China. Shanghai Archives of Psychiatry, v. 23, n. 6, p. 329-337, 2011. 